\title{
CORRECTION
}

\section{Recovery and Prediction of Bimanual Hand Use After Stroke}

In the Research Article "Recovery and Prediction of Bimanual Hand Use After Stroke" by Plantin et al. ${ }^{1}$, the Outcome-Ad-AHA-R2 column of eTable1 contained incorrect values. A corrected version is available at http://doi.org/10.5281/zenodo.5054068 as Version 2. The authors regret the error.

\section{REFERENCE}

${ }^{1}$ Plantin J, Verneau M, Godbolt AK, et al. Recovery and Prediction of bimanual hand use after stroke. Neurology. 2021;97(7):e706-e719.

Neurology ${ }^{\circledR}$ Published Ahead of Print articles have been peer reviewed and accepted for publication. This manuscript will be published in its final form after copyediting, page composition, and review of proofs. Errors that could affect the content may be corrected during these processes. 


\section{Neurology}

\section{Recovery and Prediction of Bimanual Hand Use After Stroke \\ Neurology published online August 31, 2021 \\ DOI 10.1212/WNL.0000000000012717}

This information is current as of August 31, 2021

Updated Information \&

Services

Permissions \& Licensing

Reprints including high resolution figures, can be found at:

http://n.neurology.org/content/early/2021/08/30/WNL.0000000000012717. citation.full

Information about reproducing this article in parts (figures,tables) or in its entirety can be found online at:

http://www.neurology.org/about/about_the_journal\#permissions

Information about ordering reprints can be found online:

http://n.neurology.org/subscribers/advertise

Neurology ${ }^{\circledR}$ is the official journal of the American Academy of Neurology. Published continuously since 1951, it is now a weekly with 48 issues per year. Copyright (C) 2021 American Academy of Neurology. All rights reserved. Print ISSN: 0028-3878. Online ISSN: 1526-632X.

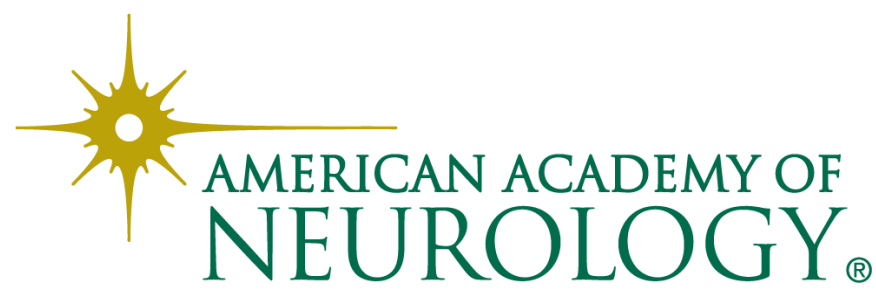

